\title{
Evaluation of three Campylobacter pylori antigen preparations for screening sera from patients undergoing endoscopy
}

\author{
FJ BOLTON, DN HUTCHINSON \\ From the Public Health Laboratory, Preston, Lancashire
}

SUMMARY A surface antigen (SA), acid glycine extract (AGE), and urease preparation (UP) were evaluated using sera from patients undergoing endoscopy and from subjects with gastric or duodenal ulcers. Sera were tested for the presence of IgG and IgA antibodies by a conventional indirect enzyme linked immunosorbent assay (ELISA). In patients with confirmed Campylobacter pylori associated gastritis, raised IgG antibody titres were indicated by absorbance values of $\geqslant 500, \geqslant 500$, and $\geqslant 1500$ for the SA, AGE, and UP, respectively. Corresponding values for the IgA assay were $\geqslant 500, \geqslant 500$, and $\geqslant 1000$. The specificity of the IgG assays were $94 \%, 92 \%$, and $90 \%$ for the AGE, SA, and UP, respectively. In contrast, the UP was the most sensitive (97\%); the other two antigen preparations gave values of $82 \%$. In the IgA assay the UP showed the greatest specificity $(90 \%)$ and sensitivity $(90 \%)$. The predictive value for a true positive for the $\mathrm{IgG}$ assay was the same for all antigens $(93 \%)$, whereas the UP gave a predictive value for a true negative of $96 \%$ compared with $79 \%$ for the other two antigen preparations. Of the patients with gastric or duodenal ulcers, raised antibody titres to SA were found in $72 \%(\mathrm{IgG})$ and $73 \%(\mathrm{IgA})$, to AGE in $75 \%(\mathrm{IgG})$ and $63 \%(\operatorname{IgA})$, and to $\mathrm{UP}$ in $77 \%$ (IgG) and $75 \%(\operatorname{IgA})$. The use of a urease antigen preparation to determine IgG antibody is recommended for screening patients undergoing endoscopy.

Of the methods used to study the antibody response to Campylobacter pylori, one of the most common is enzyme linked immunosorbent assay (ELISA). Several antigen preparations have been used with this method. In a previous study we used a surface antigen,' other workers have described an acid-glycine extract, ${ }^{23}$ and more recently an antigen preparation rich in $C$ pylori urease has been used. ${ }^{4}$ The present study was undertaken to evaluate these three antigen preparations and to determine their efficacy in the screening of patients undergoing endoscopy.

\section{Material and methods}

Three $C$ pylori antigen preparations were made as described previously: surface antigen (SA) ${ }^{1}$ used at 0.5 $\mathrm{mg} / \mathrm{l}$, acid glycine extract (AGE) ${ }^{3}$ used at $2.5 \mathrm{mg} / \mathrm{l}$, and a urease preparation (UP) 4 used at $10 \mathrm{mg} / \mathrm{l}$.

The sera tested comprised 115 serum samples from patients undergoing endoscopy and 84 serum samples from patients with gastric or duodenal ulcers.

Serum samples were diluted $1 / 100$ for the IgA assays

Accepted for publication 2 March 1989 and $1 / 1000$ for the IgG assay. These were tested by a conventional indirect ELISA using a peroxidase$\mathrm{H}_{2} \mathrm{O}_{2}$-ortho phenylenediamine detection system and read at a wavelength of $490 \mathrm{~nm} .^{5}$ All results were recorded and expressed as absorbance $\times 1000$. Positive and negative control sera were included in each batch of tests.

\section{Results}

IgG antibody responses in both sets of patients are shown in table 1. Absorbance values of $\geqslant 500$ for $\mathrm{SA}$, $\geqslant 500$ for AGE, and $\geqslant 1500$ for UP were selected as indicative of a raised IgG titre. The percentage of patients with gastritis, $C$ pylori, and raised antibody titres was $82 \%$ for SA and AGE and $97 \%$ for UP. In contrast, the percentage of patients without gastritis, no $C$ pylori, but with raised titres was $8 \%$ for SA, $6 \%$ for AGE, and $10 \%$ for UP. The proportion of raised titres in those patients with gastric or duodenal ulcers was $72 \%$ for SA, $75 \%$ for AGE, and $77 \%$ for UP.

IgA antibody responses in both sets of patients are shown in table 2. Absorbance values indicative of raised IgA titres were $\geqslant 500$ for $\mathrm{SA}$ and $\mathrm{AGE}$ and 
Table 1 Distribution of IgG antibody responses determined using three $C$ pylori antigen preparations

\begin{tabular}{|c|c|c|c|c|c|c|}
\hline \multirow{2}{*}{$\begin{array}{l}\text { Clinical } \\
\text { group }\end{array}$} & \multirow{2}{*}{$\begin{array}{l}\text { Antigen } \\
\text { preparations }\end{array}$} & \multicolumn{5}{|c|}{ No of samples giving absorbance values $(\times 1000)$} \\
\hline & & $<500$ & $<750$ & $<1000$ & $<1500$ & $\geqslant 1500$ \\
\hline $\begin{array}{l}\text { Gastritis* and } C \text { pylori } \\
\text { detected }+(n=67)\end{array}$ & $\begin{array}{l}\text { SA } \\
\text { AGE } \\
\text { UP }\end{array}$ & $\begin{array}{r}12 \\
12 \\
0\end{array}$ & $\begin{array}{r}13 \\
12 \\
0\end{array}$ & $\begin{array}{r}11 \\
13 \\
2\end{array}$ & $\begin{array}{r}19 \\
13 \\
0\end{array}$ & $\begin{array}{l}12 \\
17 \\
65\end{array}$ \\
\hline $\begin{array}{l}\text { No gastritis and } C \text { pylori } \\
\text { not detected }(n=48)\end{array}$ & $\begin{array}{l}\text { SA } \\
\text { AGE } \\
\text { UP }\end{array}$ & $\begin{array}{l}44 \\
45 \\
30\end{array}$ & $\begin{array}{l}2 \\
2 \\
8\end{array}$ & $\begin{array}{l}0 \\
1 \\
4\end{array}$ & $\begin{array}{l}2 \\
0 \\
1\end{array}$ & $\begin{array}{l}0 \\
0 \\
5\end{array}$ \\
\hline $\begin{array}{l}\text { Gastric or duodenal ulcers } \\
(n=84)\end{array}$ & $\begin{array}{l}\text { SA } \\
\text { AGE } \\
\text { UP }\end{array}$ & $\begin{array}{r}24 \\
21 \\
7\end{array}$ & $\begin{array}{r}24 \\
18 \\
3\end{array}$ & $\begin{array}{r}10 \\
12 \\
6\end{array}$ & $\begin{array}{r}16 \\
15 \\
3\end{array}$ & $\begin{array}{l}10 \\
18 \\
65\end{array}$ \\
\hline
\end{tabular}

*Histological diagnosis using the criteria of Whitehead et al ${ }^{6}$

+Culture or silver stain.

Table 2 Distribution of $\operatorname{Ig} A$ antibody responses determined using three $C$ pylori antigen preparations

\begin{tabular}{|c|c|c|c|c|c|c|}
\hline \multirow{2}{*}{$\begin{array}{l}\text { Clinical } \\
\text { group }\end{array}$} & \multirow{2}{*}{$\begin{array}{l}\text { Antigen } \\
\text { preparations }\end{array}$} & \multicolumn{5}{|c|}{ No of samples giving absorbance values $(\times 1000)$} \\
\hline & & $<250$ & $<500$ & $<750$ & $<1000$ & $>1000$ \\
\hline $\begin{array}{l}\text { Gastritis* and } C \text { pylori } \\
\text { detected }+(n=67)\end{array}$ & $\begin{array}{l}\text { SA } \\
\text { AGE } \\
\text { UP }\end{array}$ & $\begin{array}{l}1 \\
5 \\
0\end{array}$ & $\begin{array}{r}12 \\
18 \\
1\end{array}$ & $\begin{array}{r}24 \\
18 \\
2\end{array}$ & $\begin{array}{r}11 \\
10 \\
7\end{array}$ & $\begin{array}{l}19 \\
16 \\
57\end{array}$ \\
\hline $\begin{array}{l}\text { No gastritis and } C \text { pylori } \\
\text { not detected }(n=48)\end{array}$ & $\begin{array}{l}\text { SA } \\
\text { AGE } \\
\text { UP }\end{array}$ & $\begin{array}{r}7 \\
18 \\
7\end{array}$ & $\begin{array}{l}26 \\
19 \\
20\end{array}$ & $\begin{array}{r}13 \\
9 \\
12\end{array}$ & $\begin{array}{l}2 \\
0 \\
4\end{array}$ & $\begin{array}{l}0 \\
2 \\
5\end{array}$ \\
\hline $\begin{array}{l}\text { Gastric or duodenal ulcers } \\
(n=84)\end{array}$ & $\begin{array}{l}\text { SA } \\
\text { AGE } \\
\text { UP }\end{array}$ & $\begin{array}{l}3 \\
8 \\
4\end{array}$ & $\begin{array}{r}20 \\
23 \\
4\end{array}$ & $\begin{array}{r}25 \\
26 \\
4\end{array}$ & $\begin{array}{r}17 \\
16 \\
9\end{array}$ & $\begin{array}{l}19 \\
11 \\
63\end{array}$ \\
\hline
\end{tabular}

*Histological diagnosis using the criteria of Whitehead et al ${ }^{6}$

+Culture or silver stain.

Table 3 Percentage specificity, sensitivity, and predictive values for three $C$ pylori antigen preparations

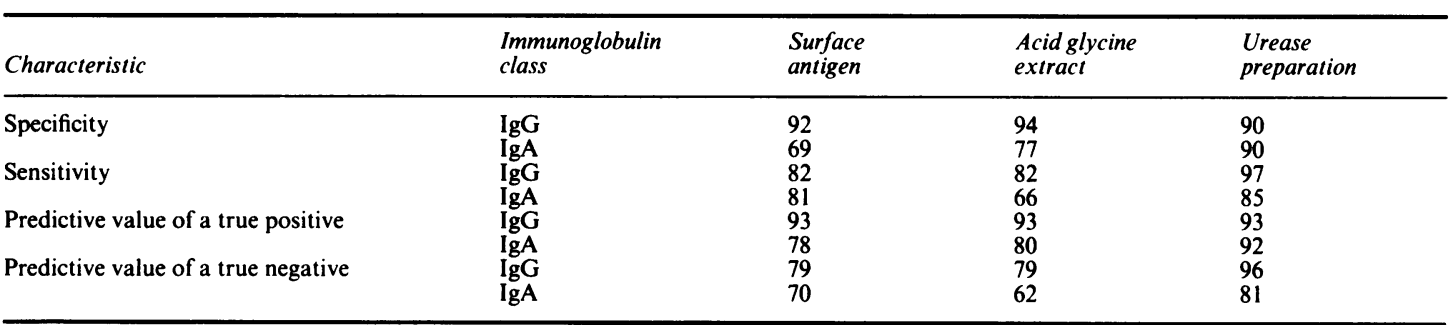

$\geqslant 1000$ for UP. The percentage of patients with gastritis, $C$ pylori, and raised titres was $81 \%$ for SA, $66 \%$ for AGE, and $85 \%$ for UP. In contrast, the percentage values for patients without gastritis, no $C$ pylori, but with raised titres was $31 \%$ for SA, $23 \%$ for AGE, and $10 \%$ for UP. For patients with gastric or duodenal ulcers significantly raised titres were $73 \%$ with SA, $63 \%$ with AGE and $75 \%$ with UP.

Specificity, sensitivity, and predictive values of the three antigen preparations are presented in table 3. The AGE antigen preparation showed the greatest specificity (94\%) in the IgG assay; the UP was the most specific in the IgA assay ( $90 \%)$. The UP showed the greatest sensitivity in both the IgG $(97 \%)$ and the IgA
$(85 \%)$ assays. Overall, all three antigen preparations showed greater specificity and sensitivity in the IgG assay than in the IgA assay.

All three antigen preparations gave an identical predictive value of $93 \%$ for a true positive result in the IgG assay but the UP was the most predictive in the IgA assay (92\%). The UP was also the most predictive of a true negative in the IgG assay $(97 \%)$ and the IgA assay $(81 \%)$.

The combinations of the results with the three antigen preparations in the IgG assay are shown in table 4. Of those patients with gastritis and organisms detected, four had raised IgG antibody titres to a single antigen preparation alone and one patient was 
Table 4 IgG antibody to $C$ pylori detected using three antigen preparations

\begin{tabular}{|c|c|c|c|c|c|}
\hline \multicolumn{3}{|c|}{ Results with antigen preparations } & \multicolumn{3}{|c|}{ No of samples with raised IgG antibody detected in each clinical group } \\
\hline $\begin{array}{l}\text { Surface } \\
\text { antigen } \\
(\geqslant 500)^{*}\end{array}$ & $\begin{array}{l}\text { Acid-glycine } \\
\text { extract } \\
(\geqslant 500)\end{array}$ & $\begin{array}{l}\text { Urease } \\
\text { preparation } \\
(\geqslant 1500)\end{array}$ & $\begin{array}{l}\text { Gastritis } \\
\text { C pylori } \\
\text { detected } \\
(n=67)\end{array}$ & $\begin{array}{l}\text { No gastritis } \\
\text { C pylori } \\
\text { not detected } \\
(n=48)\end{array}$ & $\begin{array}{l}\text { Patients with } \\
\text { gastric or } \\
\text { duodenal ulcers } \\
(n=84)\end{array}$ \\
\hline $\begin{array}{l}+ \\
+ \\
+ \\
+ \\
- \\
- \\
-\end{array}$ & $\begin{array}{l}+ \\
+ \\
- \\
\overline{+} \\
+ \\
+ \\
-\end{array}$ & $\begin{array}{l}+ \\
+ \\
+ \\
+ \\
+ \\
+ \\
-\end{array}$ & $\begin{array}{r}47 \\
0 \\
8 \\
0 \\
7 \\
1 \\
3 \\
1\end{array}$ & $\begin{array}{r}2 \\
0 \\
2 \\
0 \\
1 \\
0 \\
0 \\
43\end{array}$ & $\begin{array}{r}49 \\
6 \\
3 \\
2 \\
7 \\
1 \\
3 \\
13\end{array}$ \\
\hline
\end{tabular}

*Absorbance value indicating significantly raised antibody titres.

negative with all of the antigen preparations. Furthermore, this patient did not show raised IgA antibody titres to any of the antigen preparations. Five patients without gastritis and no $C$ pylori had raised antibody titre to two or more antigen preparations. Of these five patients, three showed evidence of raised IgA antibody titres (two showed raised IgG antibody with all three antigen preparations and one showed raised IgG antibody with SA and UP). Six of the 84 patients with ulcers showed raised titres to a single antigen preparation and 13 were negative.

\section{Discussion}

Antigen preparations used for serodiagnosis or epidemiological surveys of $C$ pylori associated gastritis should have high levels of specificity and sensitivity. The three antigen preparations evaluated in this study are relatively crude preparations and contain multiple protein bands when examined by sodium dodecyl sulphate-polyacrylamide gel electrophoresis (SDSPAGE) (results not shown). The acid glycine extract (AGE) prepared in the present study produced an almost identical protein profile as similar extracts prepared by other workers. ${ }^{23}$ Moreover, the protein profile of the surface antigen (SA) was very similar to that obtained with the AGE, indicating that similar antigens are present in both preparations. Although the SA and AGE are crude preparations, they gave similar levels of specificity ( 92 and $94 \%$ ) and sensitivity $(82 \%)$ in the IgG ELISA. Either of these two preparations, therefore, could be used in an ELISA but the SA is easier to prepare. The urease preparation was the most sensitive (97\%) and was slightly less specific $(90 \%)$ than the other two antigen preparations. SDS-PAGE analysis of this preparation has shown that it contains many of the protein bands found in the SA and AGE, plus additional bands, and is rich in urease. It is therefore difficult to state which of the proteins are acting as antigens in the ELISA and therefore further Western blot studies are necessary to elucidate the role of the cellular proteins and urease proteins present in this preparation. This crude urease preparation is, however, a useful starting point for purification of the urease antigen of $C$ pylori and as this is an important antigen it is likely to be used in the development of future ELISA tests.

Problems of specificity are most likely to occur with preparations containing proteins shared by other organisms, in particular $C$ jejuni. The flagellar proteins of $C$ pylori are known to cross react with antibodies produced against $C$ jejuni. ${ }^{2}$ The $\mathrm{SA}$ and AGE preparations contained less of these proteins than the UP and this may explain the difference in specificity between these antigens. In a previous study Dent $e t$ al reported that their urease preparation had a specificity of $79 \%,{ }^{4}$ but in our assay this preparation gave an improved specificity of $90 \%$. This may be due to the use of a higher dilution of test sera in our study and hence a diluting out effect of cross reacting antibody.

Other factors can also contribute to the determination of the specificity of the results obtained, the most important being the technique used to decide if a patient has a gastritis and $C$ pylori present in the stomach. In the present survey this was done by examining biopsy specimens. Poor quality of specimens, presence of intestinal metaplasia, and patchy distribution of both organisms and gastritis can lead to an underestimation of the true incidence of infection. In our study we found five patients who seemed to give positive serological reactions in the IgG assay. Two of these patients were probably incorrectly classified as giving false positive results because both showed raised IgG and IgA antibody titres to all three antigen preparations; one was designated as having duodenal ulcer and the other patient had a gastric ulcer. Only a single "antral" biopsy specimen was collected from both patients. If these two patients were treated as showing true positive results then the specificity and predictive value of the ELISA tests with all three antigen preparations would be enhanced.

The three other patients probably gave genuine false 
positive results because there was no histological or clinical evidence to contradict the serological results, although one of these patients had raised IgG and $\operatorname{IgA}$ antibodies to $C$ pylori.

The urease preparation was the most sensitive $(97 \%)$, gave the highest predictive values, and had a probable specificity of $93 \%$ in the IgG-ELISA. It is therefore the antigen preparation of choice for ELISA tests, and our studies suggest that estimation of the IgG titre alone is necessary for screening patients attending endoscopy clinics.

\section{References}

1 Musgrove C, Bolton FJ, Krypczyk AM, et al. Campylobacter pylori: clinical, histological, and serological studies. $J$ Clin Pathol 1988;41:1316-21.
2 Newell DG. Human serum antibody response to the surface protein antigens of Campylobacter pyloridis. Serodiagnostic Immunology and other Infectious Diseases 1987;1:209-17.

3 Goodwin CS, Blincow E, Peterson G, et al. Enzyme-linked immunosorbent assay for Campylobacter pyloridis: correlation with presence of $\mathrm{C}$ pyloridis in the gastric mucosa. $J$ Infect Dis 1987;155:488-94.

4 Dent JC, McNulty CAM, Uff JS, et al. Campylobacter pylori urease: a new serological test. Lancet 1988;i:1002.

5 Voller A, Bidwell DE, Bartlett A. The enzyme linked immunosorbent assay (ELISA): A guide with abstracts of microplate applications. Summerfield House: Guernsey, 1979:18-19.

6 Whitehead R. Mucosal biopsy of the gastro intestinal tract. 3rd ed. Philadelphia: W B Saunders, 1984:41-58.

Requests for reprints to: Dr F J Bolton, Public Health Laboratory, Royal Infirmary, Meadow Street, Preston PR1 6PS, England. 